Open Access

\title{
Comparison and contrast of Chinese curricula between China and Singapore: challenges and prospects
}

Min Huang ${ }^{1^{*}}$ and Francis Bond ${ }^{2}$

\author{
* Correspondence: \\ minmin20160307@gmail.com \\ ${ }^{1}$ College of International Studies, \\ Southwest University, Tian Sheng \\ Road, Beibei District, Chongqing \\ 400715, China \\ Full list of author information is \\ available at the end of the article
}

\begin{abstract}
In this paper, Chinese curricula in the contexts of China and Singapore on primary level are compared and contrasted by both quantitative (Word Segmenter and Text Analyzer) and qualitative methods (in-depth thematic analysis). The research shows challenges for educational administrators, teachers and other professional staff in Chinese education on the aspects of applying information and communication technology, implementing individualized and autonomous teaching and learning, balancing different teaching objectives, understanding students' cognitive and psychological varieties, readjusting teachers' roles as organizer, facilitator and instructor, and aligning formative assessment and summative assessment. Meanwhile, the research also demonstrates and rationalizes the prospects of Mobile Assisted Language Learning (MALL) in Chinese teaching and the glocalization of Chinese curricula in the future. Further, the research will help people know more about diverse social linguistic contexts in China and Singapore, the different essence of first language (L1) and second language (L2) teaching, and the complexity and arduousness of language teaching in practice.

Keywords: Chinese curriculum, Comparison, Contrast, Challenges, Prospects
\end{abstract}

\section{Introduction}

Research background and purposes

In China, the learning of Chinese, as an official course at schools, can date back to more than 100 years ago in Qing dynasty, when ancient Chinese was studied exclusively. With the independence of the People's Republic of China (PRC) in 1949, Chinese, as an absolute and indispensible course in educational system, was redesigned and re-implemented for Chinese people. From kindergartens to universities, Chinese course appears as an obligatory one taken by students. Its evaluation score is an important decisive indicator for students' academic achievement, and holds a large proportion in national high-stake entrance examination called Gaokao (高考), which is regarded by Chinese people as vital for their children's future. There is a possibility that the total score of Chinese subject in entrance examination will rise from 150 points to 180 points in the near future, which manifests Chinese language's dominative role in the educational context. Being the first language (L1) and mother language in China, Chinese (Mandarin) is promoted by Chinese government as the only official 
common language used by different ethnic nationalities around the country to communicate with from 1955 (Zhou 2001). Meanwhile, Popularizing Mandarin Chinese Movement was advocated from the year of 1997, with national constitution laws guaranteeing its irreplaceable place. Around the world, Chinese (Mandarin) has emerged as a prosperous language being studied by non-Chinese people for a wide range of purposes, especially with China's fast-growing economic development and frequent involvement in world affairs. According to data released by Chinese Ministry of Education, more than 100 million people globally were learning Chinese as a second, foreign or additional language in 2011, not to mention the mainland Chinese people with a population of as many as nearly 1.4 billion at the end of 2015 (Chinese Ministry of Education 2006).

In Southeastern Asia, Singapore is a country which is comprised of three major ethnic groups in the following relatively stable proportions: $75 \%$ Chinese, $13.7 \%$ Malaysians, $8.7 \%$ Indians and $2.6 \%$ others, from as early as its inception as an independent country in 1969. Its economy development once ranked the second only to USA as the most competitive country globally in 2007. It is still a country with dynamic development potential now. Singapore's bilingual education was stated to have made great contribution to prepare bilingual talents for this country's booming. In regards to bilingual education in Singapore, people are required to study both English as working language and their mother tongues as the second languages (L2) along the way of education from primary to university. Specifically, Singaporean Chinese will study Chinese (Mandarin), Malaysians Malay, and Indians Tamil. Singapore government believes that the study of mother tongues will make students sustain the traditional bonds and, hence, possess the ability to communicate with people who share the similar cultures with them in the world. Although this is thought as English-knowing bilingual policy which embodies apparently the important role of English in working and educational contexts, mother tongues' study has never been neglected but strengthened, with clear evidences from the establishment of both Chinese Language Curriculum and Pedagogy Review Committee (CLCPRC) in 2004 and Mother Tongue Language Review Committee (MTLRC) in 2010. These two committees have exerted great effect on the design, modification and implementation of language curricula in Singapore's various school levels. Meanwhile, social movements, such as Speak Mandarin Campaign, launched by former Prime Minister Lee Kuan Yew from 1979, helped to consolidate the role of Chinese in social life and its practical use in communication (Wikipedia 2016).

Chinese curricula in both countries have undergone constant shifts to cater for changed linguistic environment and social development. It brings great challenges to school administrators, teachers, students and related professionals. However, the world is developing fast without people's notice and the education has to meet this change to become more efficient and valuable in preparing talents for the future. In this study, the current Chinese curricula in China and Singapore on primary level are compared and contrasted via quantitative and qualitative research methods by the use of computational linguistic programmes and in-depth thematic analysis of texts. The results will help people know more about challenges the shift of curricula brings to educational staffs, the similarities and differences of Chinese teaching between these two Asian countries, characteristics and practices of Chinese teaching and learning as L1 and L2 
respectively, and the focused points on modern language learning. Meanwhile, the prospects on language teaching and curriculum modification will be expected in the paper, too.

\section{Definitions and related issues}

Many researchers have made great effort to distinguish the differences between curriculum and syllabus. But it is still rather unclear because different scholars present various viewpoints on this issue and in some cases these viewpoints are absolutely different (Nunan 1993). The curriculum described by Dubin and Olshtain (1986) is thought as an all-around educational-cultural philosophy for lots of subjects with reflection of a nation's political trends, contains an extensive description of general goals and also guides language teaching and learning. According to Richards (2001), language curriculum is "an interrelated set of processes that focuses on designing, revising, implementing and evaluating language programs". While syllabus is described by Breen (2001) as what will have effect on teachers and students in terms of content and ways by which teachers will deliver the content. Richards (2001) distinguishes that the difference lies in the scope. It is thought that curriculum is an umbrella word which includes syllabus, concerned with planning, implementation, evaluation, management and administration of education programs (Nunan 1993). Hall \& Hewings (2001) hold a similar view and address that curriculum covers all the issues related with planning, implementation and evaluation of a collection of language learning activities which will establish a coherent unity with definite purposes. While syllabus, on the other hand, focuses more narrowly on selecting and grading content, specifying and planning what is to be learned, listing the selection and grading of linguistic objectives, which are written down as prescription for action by teachers and learners in practice (Candlin 1984; Pienemann 1985). Seeing that the discussion of their differences is not a major concern here, the words of curriculum and syllabus are used interchangeably in this paper.

As a well-known written description and a plan in educational contexts, curriculum or syllabus, serves as one of the most important and valuable resources. Curriculum will provide an instructional framework for teachers to organize teaching activities efficiently and help students learn as effectively as possible in a language course, or an individual class on a day-to-day and cumulative basis through the entire language program (Brown 1995; Li 2008). Richards (2001) states that curriculum plays a crucial role in language teaching and learning because successful language programmes are assumed to be dependent upon curriculum development activities. Wiggins and McTighe (2007) address that curriculum is not just a list of topics or key facts and skills. It will guide teachers and students to achieve desired student performance results by implementing appropriate learning activities and assessments. Hans \& Betty (2015) believe that curriculum is the vehicle by which the development of epistemological, praxis and ontological elements can be incorporated into the life and learning of today's students, ensuring that they graduate ready and willing to make a positive difference in the world of tomorrow. Many other scholars also state that syllabus can exert a variety of purposes: as an agreement between teachers and students; as a device for communicating; as an overall plan of action for the course; as a teaching tool or resource, an artifact for teacher evaluation; as a cognitive map of the 
course to share with students; as a highly facilitator of students' learning; as an inexpensive assessment of the instructional practices instructors use in their course; as a powerful indicator of what takes place in classrooms and as evidence for accreditation (Slattery \& Carlson 2005; Thompson 2007; Cullen \& Harris 2009; Sinor \& Kaplan 2010; WillinghanMcLain 2011). The more explicit the course curriculum or syllabus in terms of objectives, content, instructional resources and grading components is, the better it enables the processing of information gained in a learning situation and the students' final grade performances as well. But the understanding of curriculum or syllabus is closely related to a number of contextual factors which determine the success of a language program, and the shift of curriculum or syllabus will definitely bring great challenges and changes for teaching and learning process.

\title{
Methods
}

In this research, qualitative and quantitative methods were combined to explore the curricula deeply. For qualitative method, in-depth thematic analysis is the way applied to get the qualitative data. Specifically, we read the curricula carefully first, then identified the themes preliminarily and developed the coding scheme accordingly. Then, we coded the curricula repeatedly with the coding message to avoid the omission of data. Lastly, comparison and contrast work was done.

For quantitative method, "Chinese Word Segmenter"(NLTK) and "Text Analyzer"(Online-Utility.org) programmes were run in a computer. "Chinese Word Segmenter"(NLTK) is a famous Python Natural Language Processing Toolkit which is a leading platform for building Python programs to work with human language data and can provide customized Chinese text sentence segmentation and divide the text into words with a space separating them. For example,

\section{Original Chinese Text:}

\begin{abstract}
当今世界, 经济全球化趋势日渐增强, 现代科学和信息技术迅猛发展, 新的交流 媒介不断出现, 给社会语言生活带来巨大变化, 对中华民族优秀传统文化的继承, 对语言文字运用的规范带来新的挑战.
\end{abstract}

\section{Segmented Chinese Text:}

当今世界, 经济全球化 趋势 日渐增强, 现代 科学 和 信息 技术迅猛发展, 新 的 交流媒介不断出现, 给社会语言生活带来巨大变化, 对 中华民族 优秀传统 文化的 继承, 对语言 文字运用的规范 带来 新 的 挑战.

The segmented text results were discussed with three Chinese native speakers to ensure that they had comprehensible and accurate segmentation results.

"Text Analyzer" (Online-Utility.org) is another programme which will allow people to find the most frequent words or phrases and the frequency of each word. It can also count number of words, characters, sentences, syllables and lexical density. The segmented texts will be input into this programme, which will process the related information of the words in the texts. 
It is assumed that in order to raise people's attention, the more important the themes are, the more frequently they will be mentioned in a curriculum by policy-makers.

\section{Results and discussion}

\section{Key words with high frequency in curricula}

The original texts of curriculum in China and Singapore were input to "Chinese Word Segmenter" programme separately and then the text results were fed into "Text Analyzer" to receive a processing. From the processed results, the top 50 Chinese noun words with high frequency were picked up from China's and Singapore's curricula respectively. Then, by matching these two results, we found 27 Chinese noun words, which appeared both in China's and Singapore's curricula. It means the ideas of these 27 noun words are highly stressed in both countries' Chinese education. To avoid the redundancy, Table 1 just shows the common shared 27 Chinese noun words. We will incorporate the discussion of this result with in-depth thematic analysis of texts in the following parts.

Table 1 Shared words with high frequency in both China's curriculum and Singapore's curriculum

\begin{tabular}{|c|c|c|c|c|c|c|}
\hline & Chinese gloss & English gloss & Freq. (China) & $\%$ (China) & Freq. (Singapore) & $\%$ (Singapore) \\
\hline 1 & 学生 & Student & 73 & 2.55 & 77 & 2.82 \\
\hline 2 & 学习 & Learning & 57 & 1.99 & 71 & 2.60 \\
\hline 3 & 课程 & Curriculum & 47 & 1.64 & 20 & 0.73 \\
\hline 4 & 评价 & Assessment & 41 & 1.43 & 27 & 0.99 \\
\hline 5 & 教学 & Teaching & 26 & 0.91 & 47 & 1.72 \\
\hline 6 & 能力 & Ability & 23 & 0.81 & 46 & 1.69 \\
\hline 7 & 发展 & Development & 21 & 0.73 & 15 & 0.55 \\
\hline 8 & 文化 & Culture & 17 & 0.60 & 16 & 0.59 \\
\hline 9 & 语言 & Language & 17 & 0.60 & 40 & 1.47 \\
\hline 10 & 资源 & Resource & 15 & 0.52 & 15 & 0.55 \\
\hline 11 & 方式 & Method & 14 & 0.49 & 6 & 0.22 \\
\hline 12 & 活动 & Activity & 12 & 0.42 & 5 & 0.18 \\
\hline 13 & 过程 & Process & 10 & 0.35 & 7 & 0.26 \\
\hline 14 & 阅读 & Reading & 10 & 0.35 & 7 & 0.26 \\
\hline 15 & 教师 & Teacher & 8 & 0.28 & 32 & 1.17 \\
\hline 16 & 内容 & Content & 8 & 0.28 & 11 & 0.40 \\
\hline 17 & 目标 & Target & 7 & 0.24 & 9 & 0.33 \\
\hline 18 & 生活 & Life & 7 & 0.24 & 9 & 0.33 \\
\hline 19 & 教育 & Education & 6 & 0.21 & 5 & 0.18 \\
\hline 20 & 设计 & Designation & 6 & 0.21 & 8 & 0.30 \\
\hline 21 & 思维 & Thinking & 6 & 0.21 & 7 & 0.26 \\
\hline 22 & 自主 & Autonomy & 6 & 0.21 & 5 & 0.18 \\
\hline 23 & 口语 & Speaking & 5 & 0.17 & 5 & 0.18 \\
\hline 24 & 探究 & Exploration & 5 & 0.17 & 6 & 0.22 \\
\hline 25 & 写作 & Writing & 5 & 0.17 & 6 & 0.22 \\
\hline 26 & 合作/协作 & Cooperation & 5 & 0.17 & 5 & 0.18 \\
\hline 27 & 学校 & School & 5 & 0.17 & 8 & 0.30 \\
\hline
\end{tabular}

*Freq. = Frequency; \% = Percentage among the whole amount of text words 


\section{Structures of Chinese curricula in two countries}

As important guiding information, curriculum's structure will provide a bird's view for people to understand its content and give a hint of curricula makers' understanding of organization of a curriculum. Meticulous study will reach the result that China's Chinese curriculum covers the following four main parts as preface, objectives, implementing suggestion and Appendix. On the other hand, Singapore's Chinese curriculum encompasses six parts as preface, course conception, objectives, course framework, subentry objectives, and implementing suggestions. What's worth to mention is that in China's curriculum an elaborate list of required Chinese characters as many as 3000 on primary level, together with a mass of recommended extracurricular reading materials, including fairies, stories, proses, literature works, is provided in the Appendix part to extend students' reading outside class. The curriculum clearly states that the amount of extracurricular reading for primary students in China is not less than 1 million words. 'Reading' is also one of the high frequency words in curriculum, see Table 1.

Extracurricular reading enables students to improve their reading proficiency, broaden their views, facilitate their language awareness, motivate their learning interest, and help accumulate writing materials, etc. Considering that primary students' are growing physiologically and psychologically and they cannot focus on one thing for a long time, it will make teachers face the challenges that how to arouse and maintain students' extracurricular reading interests, how to help and assesses their reading process, how to organize reading activities and how to include students' autonomy into reading. Meanwhile, the modern information is increasing in an explosive way, especially with the wide application of information technology, so the updating of reading material and the change of reading media are also the problems educationists will face. In Singapore's syllabus, the application of information technology is highly stressed and an extra section was purposefully allocated to put forward and explain it.

The use of computers in education has not been a special case any longer but becomes a primary component of language learning and language use (Warschauer 1999). ICT (Information and Communication Technology) is able to offer valuable alternatives to teachers and educational institutions and evaporate borders and distance in current global world. It enables learners to get access to useful language resources and communicate directly with native speakers (Jacobs \& Farewell 2003; Daly 2009). Besides, it can help to display students' learning outcomes, intensify their communicative and cognitive ability, broaden their learning content and learning space, cultivate their cooperative and autonomous study. In recent years, the mobile phone, as a common and convenient modern technology learning tool, becomes popular in classrooms and Mobile Assisted Language Learning (MALL) has arisen (Tayebeh \& Amin 2012; Yang 2013; Burston 2014; Duman et al. 2015; Adam 2016; Imtiaz et al. 2016). It can be predicted that MALL will become the common practice in language classrooms soon, where students can choose the learning materials they are interested in independently and download them conveniently, share with the friends millions of miles away as an attached file in an email, then dial an international call to inform their friends this message and receive their friends' feedback instantly. It will go beyond mobile's traditional functions and greatly change the language learning environment and teaching methods in the future. 


\section{Essence of Chinese course in two countries}

The essence of a language course reflects people's comprehension of a language's nature in a specific social context. The curricula in both countries state the rational reasons of modifying curriculum as follows: the fast development of international society, the constant shift of linguistic environment and the steadily progressive modern technology. It can be identified that external reasons are the direct motives to push the shift of a curriculum.

In China's curriculum, Chinese course is proposed to be crucially fundamental for other courses and beneficial for students' world outlook, life outlook and sense of values, which is irreplaceable by others. It also takes the functions to inherit and carry forward Chinese cultures, strengthen people's national identity, and reinforce people's unity. For that, Chinese teachers should know such two core values of Chinese course in China as instrumental value and humanity value. While as a L2 language in Singapore, Chinese course is defined as a part included in the bilingual language education and plays important constituent and coordinative roles. Its value primarily lies in the practical communicative function in people's daily life. The word "skill" is on the list of high frequency words of Singapore's curriculum. The understanding of Singapore's bilingual language education policy becomes the prior condition to comprehend its Chinese language instruction in schools.

This diverse description of Chinese course essence also asks for teachers to know the difference of essence of L1 and L2 and their close connection with notions of culture and identity. The words "culture" and "language" are on the list of high frequency words, see Table 1. In China, Chinese is the only language which is endowed with legal status to bridge the communication gap between 56 ethnic groups. Official activities of government, lessons in schools and other educational institutions, national radio and television broadcasting, films and TV drama are in Chinese mandarin language ( $\mathrm{Na} 2010$ ). Being the first language, it is also a working, educational and life language for Chinese people, and manifests a person's personal, social and integrity cultural identity. While Singapore is a multilingual and multicultural society, with English as its working language or L1 in working and educational contexts, Chinese as a mother tongue or L2 for Singaporean Chinese to keep bond with Chinese culture and communicate with in Chinese community. English is the lingua franca in Singapore society for all people. Any mother tongue cannot replace English's status in policy and in practice because the choice of any mother tongue as the inter-ethnic communication language in Singapore will be thought as the discrimination against the other mother tongues, which is not allowed by government (Antonio \& Lionel 2006). As L2, Chinese language's value in Singapore can reasonably dwell in its practical communicative function and culture bond within Chinese community and it's hard to justify it on a national identity level.

\section{Curriculum concepts of Chinese course in two countries}

Curriculum concepts covers the guiding principles of topics for a course, sets the basic criteria for learning content and explains issues closely related with teaching and learning practice, such as students' factors, learning environment, and teachers' teaching.

Some similarities on curriculum concepts can be identified in two countries, which get enlightenment from modern education theories and possess positive meaning for Chinese language teaching and learning practice. 
Firstly, both curricula state that the Chinese course should cater for primary students' linguistic, cognitive and affection development. The word "development" appears as one of the high frequency words in both curricula, see Table 1. And students' individualized situations should be considered. Individualized instruction takes the assumption that learners are different in interest and abilities of learning and challenges teachers to tailor their instruction to students' strengths and weaknesses. In language learning, it assumes that learners' conditions are various intellectually and affectionately. The variety of language learners in the aspects between personality extroversion and introversion, field independence and field dependence, visual, auditory or kinesthetic, risky and less risky remains as the research topics in language learning field and continue to impose challenges to language teachers (Stephen 2002; Susan \& Larry 2008).

Secondly, both curricula lay importance to the cultivating of students' autonomous learning ability in Chinese study. Holec (1981) introduces autonomous learning into educational context, which emphasizes learners taking charge of their own learning. These abilities involve students' establishing learning objectives, defining content and learning process, selecting methods and techniques to achieve learning objectives, monitoring the procedure of learning and evaluating what has been acquired. Autonomous learning will benefit students' learning and lifelong development (Dickinson 1987; Benson 2001; Abdual \& Suraya 2012). But teachers face the challenges of understanding and practicing the autonomous learning theory, autonomous learning psychological mechanism, effective autonomous learning strategies, and the precise teaching planning and classroom practice, etc.

Thirdly, both curricula think that the course can cultivate not only students' Chinese linguistic skills, but their emotions and morals. In China's curriculum, the Chinese course will be defined to stimulate and sustain students' love towards Chinese, enhance their morality and esthetic sentiment, develop the patriotism and establish the socialistic common dream. In Singapore's curriculum, the Chinese course will be guided by "21st century competencies core values", which covers the following ideas as respect, responsibility, integrity, caring, persistence and harmony.

One innovative idea from China's curriculum is the proposal of cultivating students' "Chinese accomplishment", which is the integration of Chinese language knowledge, proficiency, feelings, thinking patterns, morals, aesthetic, personality, and learning habits (Baidu encyclopaedia 2016). It is constituted by the hierarchical four layers. The basic one is explicit skills of Chinese listening, speaking, reading, and writing. The second one is intellectual factors which will dominate the speech act, such as linguistic knowledge. The third one is psychological factors in which people carry out linguistic behaviors, such as attitudes and motivation. The fourth one is people's traits, such as morals, and personality, see Fig. 1. It includes a person's hierarchical development needs and requirement for learning.

For Singapore's curriculum, 96 Chinese characters are refined to describe the curriculum concepts for primary Chinese course. It covers the fields of learning content, learners' factors, learning environment and teaching technologies. See Table 2 below.

\section{Curriculum objectives of Chinese course in two countries}

Stern (1992) claims that setting objects is a major step in the process of curriculum design, so great caution should be devoted to it and the desired end product of the teaching process must be defined as clearly and accurately as possible. Richards (2001) 


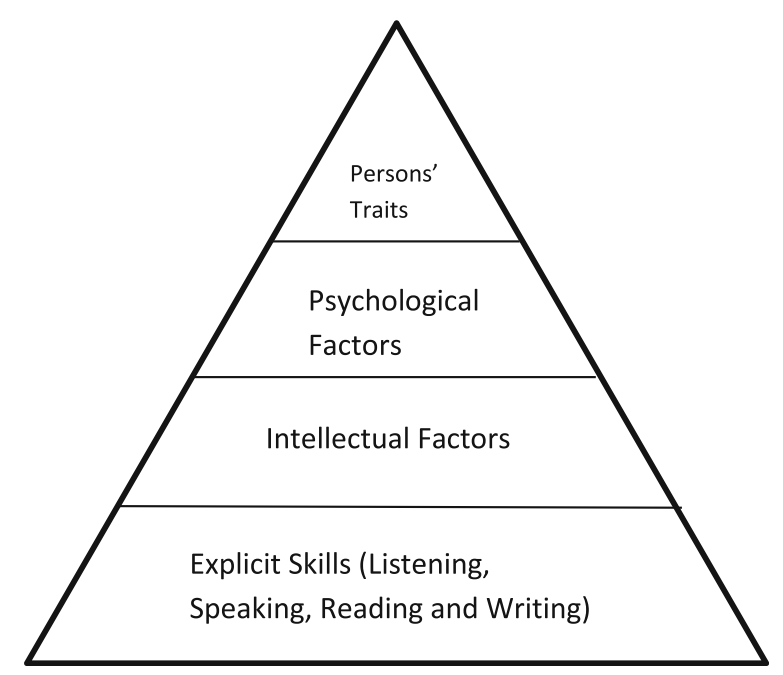

Fig. 1 Four layers of Chinese accomplishment

describes setting goals as "...not therefore, an objective scientific enterprise but a judgment call" for a course. Thus, it is crucial to understand the ultimate objectives a curriculum will try to achieve.

In Singapore's curriculum, the objectives of Chinese course are summarized as the achievements in such three aspects as linguistic competence, humanistic quality and general ability. Linguistic competence means the proficiency in Chinese listening, speaking, reading, writing, oral interaction and writing interaction. Humanistic quality include positive life values, appreciation and inheriting of Chinese culture, knowing Singapore's local customs, caring about families, society, nation and the world, respecting different cultures and carrying the intercultural communication. General ability is the ability which can be applied to access to, construct and use knowledge, analyze and solve problems, for example, thinking ability, autonomous study ability, social skills, emotion controlling ability, technology using ability and intercultural communication ability, see Fig. 2.

Figure 2 shows the relationship between different dimensions of learning objectives. It requires teachers to view a lesson's objectives from different perspectives and go beyond the linguistic result to keep a balance between these three ones, which set a higher standard for the process of teaching planning. Teachers' community can serve as a helpful resource for sharing teaching resources and help teacher achieve efficient teaching plans.

Table 2 Description of curriculum concepts of Chinese course in Singapore

\begin{tabular}{ll}
\hline Description in Chinese & English version \\
\hline 重视语言技能,实现有效沟通 & Emphasize the language skills, and realize the efficient communication \\
注重实用价值,实现乐学善用 & Stress on practical value, and realize happy learning and proficient use \\
遵循学习规律,符合认知发展 & Follow the learning rules, and conform to students' cognitive development \\
照顾个别差异,发掘学生潜能 & Cater for students' differences, and develop their potential abilities \\
培养情意品德,传承华族文化 & Nourish students' morals, and make them inherit the traditional cultures \\
促进思维发展,培养自学能力 & Facilitate students' thinking skills, and foster their autonomous study \\
结合资讯科技,增进学习效益 & Integrate the information technology, and improve the learning efficiency \\
关注学习过程落实有效评价 & Focus on students' learning process, and carry out effective evaluation \\
\hline
\end{tabular}




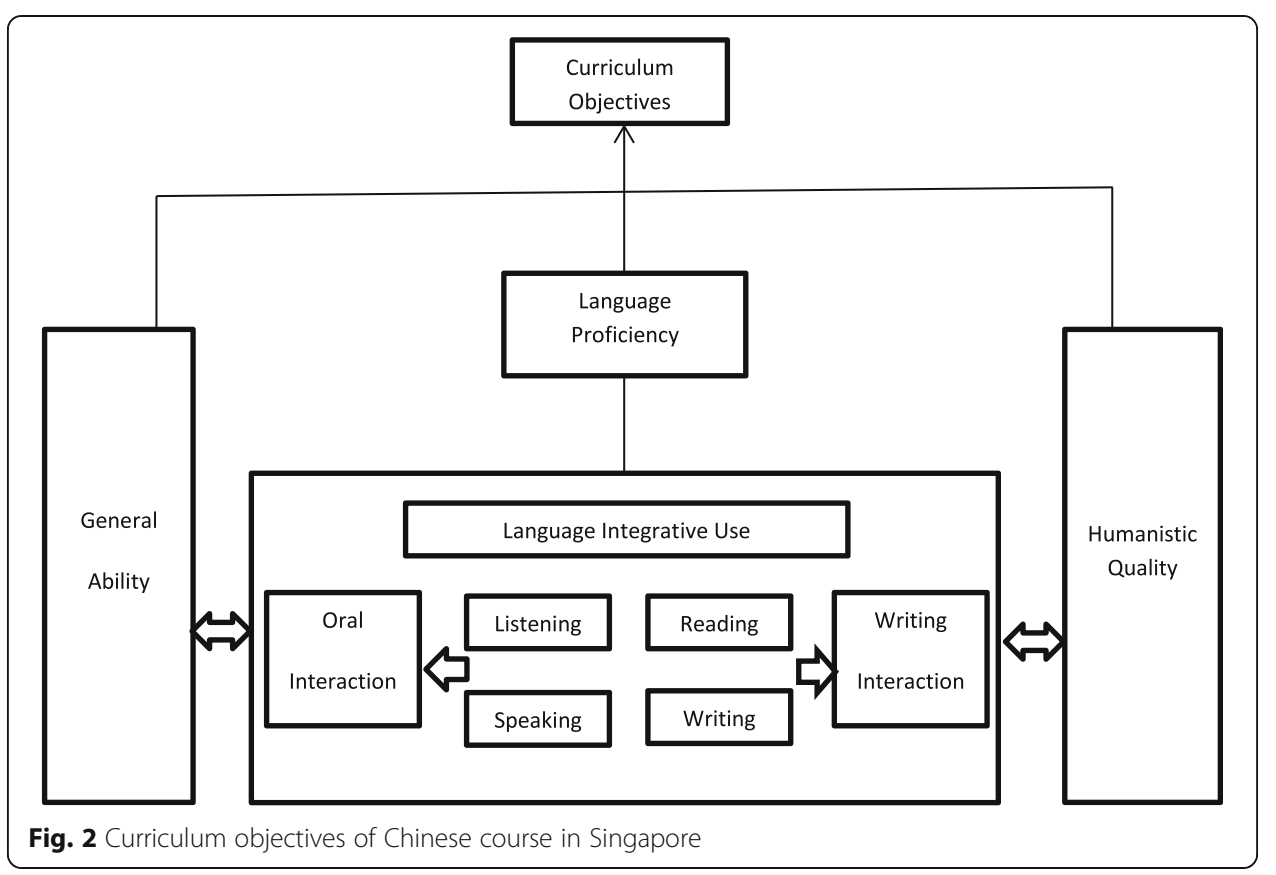

While in China's curriculum, the Chinese course is targeted to balance three relationships of knowledge and skills, process and steps, emotional attitudes and values. See Fig. 3.

To achieve a balance between these three relationships, Chinese teachers face the challenge of cultivating students' Chinese core values in Chinese lessons, such as patriotism, collectivism, socialism morals, and right emotional attitudes as cooperation, aesthetics, innovation, etc. Teachers should understand the equal importance of linguistic knowledge and cultural knowledge and take efforts to incorporate them into lessons to cultivate students' interest on contemporary life and multi-cultures with their linguistic development. Meanwhile, students' confidence of learning Chinese, autonomous learning ability, scientific thinking, imaginative thinking, inquiry study and learning strategies are also the teaching objectives Chinese teachers should plan to achieve in Chinese lessons.

\section{Teaching suggestion for Chinese course in two countries}

Teaching suggestion will provide a practical advice for schools and teachers to undertake teaching behavior and guarantee the teaching efficiency, which is the decisive element in the application of curriculum. The curricula in two countries state that

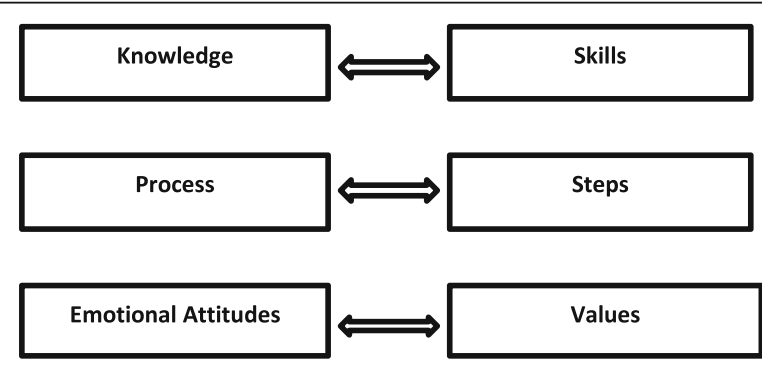

Fig. 3 Three relationships of curriculum objectives in China 
students' ability of Chinese practical use is crucial. Curricula objectives can be achieved with the combinational efforts from teachers' teaching and students' learning, with high frequency of words "students", "learning", "teacher", "teaching" in Table 1. For students, learners' confidence, initiative of learning, inquiry and autonomy of learning are laid importance on. For teachers, their teaching methodology, such as communicative teaching and task-based teaching are strongly suggested. China's curriculum clearly states that teachers are activities' organizers and guides and teaching process should happen based on the equal status of teachers and students. It conforms to the shifts of teachers' roles in recent language curriculum reform where teachers are defined as an organizer, facilitator and instructor for students' learning rather than dominator and controller in traditional teaching (Dai \& Hu 2009). The teaching suggestion is summarized in Table 3. Every piece of suggestion provides a helpful guide for teachers' teaching practice and takes shape as challenges for teachers as well.

\section{Assessment for Chinese course}

Assessment in education means all the activities that teachers and students undertake to get information that can be used diagnostically to alter teaching and learning (Black \& William 2010). It can provide the necessary data for teacher accountability purposes and serves as an integral component of the teaching process (Reynolds et al. 2006). The alignment of formative assessment and summative assessment is the prevalent idea in education field temporarily. Because either of them sheds light on some aspects of teaching or learning and both play important roles in the learning process.

Formative assessments are defined as activities carried out by teachers or students themselves to provide useful feedback information to modify teaching and learning process (Black \& William 2010). It can provide an ongoing source of information to

Table 3 Teaching suggestion of Chinese course in two countries

\begin{tabular}{ll}
\hline CHINA & Singapore \\
\hline 中文:充分发挥师生双方在教学中的主动性和创造性 & 中文:照顾学习差异,建立学习信心 \\
$\begin{array}{l}\text { English: Unleash the initiatives of both teachers and } \\
\text { students }\end{array}$ & $\begin{array}{l}\text { English: Cater for students' differences in learning } \\
\text { and try to establish their learning confidence }\end{array}$ \\
中文:教学中努力体现语文的实践性和综合性 & 中文:重视显性教学,优化教学设计 \\
English: Embody Chinese course's practicality and & $\begin{array}{l}\text { English: Stress on explicit teaching and optimize } \\
\text { teaching planning }\end{array}$ \\
中文:重视情感、态度、价值观的正确导向 & 中文:加强交际互动,发展语言能力 \\
English: Stress on the forming and guiding in & English: Facilitate the interactive activities and \\
students' emotions, life attitudes and values & develop students' linguistic competence \\
中文:重视培养学生的创新精神和实践能力 & 中文:重视生活运用,拓宽学习渠道 \\
English: Deal with the relationship between basic & $\begin{array}{l}\text { English: Relate students' learning with life in family } \\
\text { language competence and creative ability }\end{array}$ \\
中文:根据学生的发展规律和语文学习的特点,选择合 & 中文:培养情意品德,发展自主学习 \\
适的教学策略 &
\end{tabular}

English: Abide by students' development rules and Chinese language learning rules, and choose appropriate teaching strategies
English: Cultivate students' morals and develop their autonomous learning

中文:探索有效方法,提高专业水平

English: Explore efficient teaching methods and improve the professionalism 
teachers about students' learning during the learning process instead of after a period of instruction and help teachers adjust their instruction to make their teaching more efficient. As Yorke (2003) states the main contribution of formative assessment is proving students' constant performance information to teachers.

While summative assessments are generally thought as high-stake because they serve as final assessments of the degree of students' performance (Gardner 2010). Summative assessments can be used to determine eligibility for special programs, to assess if a student should advance to the next grade level, to provide career guidance, or to assess qualifications for awards (Harlen \& Gardner 2010).

The idea of aligning both means of assessment demonstrates that the formative assessments reflect learning activities that appropriately prepare students for the summative assessment of the outcomes and offer them and their teachers' opportunities to diagnose where students are in relation to the outcomes assessed in the summative assessment (Knight 2000; Yorke 2003; William 2011).

Both curricula in China and Singapore stress on the importance and practice of formative and summative assessment in Chinese language teaching. To do efficient formative and summative assessment, stakeholders' efforts, including teaching administrators, teachers, students, parents, community and other professional persons, should be combined to make the assessment more all-around and objective. Teaching administrators should support the reform of assessment and take language ability instead of exam score as assessed result and help to form a relaxing school teaching and learning atmosphere for teachers and students. For teachers, they must know how to use efficient assessment ways, such as portfolio, face-to-face meeting, questionnaire, to collect students' learning information, how to use authentic assessment tasks to evaluate students' real performance, how to interpret the scores correctly and how to use appraisal and encouraging remarks to avoid the hurting of slower students, etc. Meanwhile, parents, students, community are also the assessment entities. Parent's assessment, students' self or peer assessment, community's assessment should be encouraged and developed especially. The importance of 'assessment' can be witnessed on the list of high frequency words, see Table 1.

\section{Conclusions}

Through comparing and contrasting the aspects of essence, curriculum concepts, curriculum objectives, teaching suggestion, and assessment, we are informed with in this study the challenges Chinese teachers will face in China and Singapore in terms of language teaching essence, teaching technology, students' individual factors, teachers' roles, assessment, etc. Meanwhile, the similarities and differences of Chinese teaching between these two Asian countries, and characteristics and practices of Chinese teaching and learning as L1 and L2 respectively can be spotted, too.

With the general curriculum reform, the idea of glocalization is suggested to be integrated into the Chinese language curriculum in the near future. The reality provides rational reasons for the appearance of this notion. Students are living and will still live in a globalized world as professionals and citizens. Globalization is not an unfamiliar word to people, which is coined to describe the "heightened form of time/space compression" and the "inevitable" competition among the territories and countries in the world (Maguire 2002). But local contexts are also existing to exert their effect and appear as competitive power with global influence. Meanwhile the post-method rejects 
the belief in one-size-fits-all method, and gives rise to the need to localize the teaching materials and teaching methodologies in order to better suit the particular language needs and wants of each specific context (Ahmadian \& Rad 2014). Thus, glocalization was introduced as a reconciling idea by Robertson 1995. To glocalizing curriculum, curriculum-makers, administrators, teachers, and related professionals should connect the learning outcomes, assessment tasks, teaching methods and supportive service of a program to the international, intercultural, global dimension and local context and focus on what students will experience, instead of what they will learn and how they will demonstrate their learning (Ahmadian \& Rad 2014; Betty 2014; Hans \& Betty 2015). Therefore, language curriculum needs to ask for the glocalization of learning materials and teaching methods, the relation of instructional issues with both international context and local reality, the involvement of learning cooperation on international and local levels, the communication with people from other countries, and the varieties of assessment tasks requiring both students' overseas and domestic learning experience, etc., to achieve students' linguistic, cognitive, emotional and humanistic quality development as a whole.

\section{Appendix}

Table 4 Words with high frequency in China's curriculum (Lexical density: 24.4677)

\begin{tabular}{|c|c|c|c|c|c|c|c|}
\hline Chinese gloss & English gloss & Freq. & $\%$ & Chinese gloss & English gloss & Freq. & $\%$ \\
\hline 语文 & Chinese & 89 & 3.11 & 目标 & Target & 7 & 0.24 \\
\hline 学生 & Student & 73 & 2.55 & 功能 & Function & 7 & 0.24 \\
\hline 学习 & Learning & 57 & 1.99 & 生活 & Life & 7 & 0.24 \\
\hline 课程 & Curriculum & 47 & 1.64 & 传统 & Tradition & 7 & 0.24 \\
\hline 评价 & Assessment & 41 & 1.43 & 素养 & Literacy & 7 & 0.24 \\
\hline 教学 & Teaching & 26 & 0.91 & 教育 & Education & 6 & 0.21 \\
\hline 能力 & Ability & 23 & 0.81 & 设计 & Designation & 6 & 0.21 \\
\hline 发展 & Development & 21 & 0.73 & 整体 & Integrity & 6 & 0.21 \\
\hline 运用 & Usage & 21 & 0.73 & 交际 & Communication & 6 & 0.21 \\
\hline 文化 & Culture & 17 & 0.60 & 情感 & Emotion & 6 & 0.21 \\
\hline 语言 & Language & 17 & 0.60 & 创新 & Creation & 6 & 0.21 \\
\hline 资源 & Resource & 15 & 0.52 & 思维 & Thinking & 6 & 0.21 \\
\hline 方式 & method & 14 & 0.49 & 自主 & Autonomy & 6 & 0.21 \\
\hline 活动 & Activity & 12 & 0.42 & 口语 & Speaking & 5 & 0.17 \\
\hline 文字 & Character & 11 & 0.39 & 方面 & Aspect & 5 & 0.17 \\
\hline 实践 & Practice & 11 & 0.39 & 探究 & Exploration & 5 & 0.17 \\
\hline 社会 & Society & 10 & 0.35 & 写作 & Writing & 5 & 0.17 \\
\hline 过程 & Process & 10 & 0.35 & 合作 & Cooperation & 5 & 0.17 \\
\hline 精神 & Spirit & 10 & 0.35 & 自我 & Self & 5 & 0.17 \\
\hline 阅读 & Reading & 10 & 0.35 & 态度 & Attitude & 5 & 0.17 \\
\hline 特点 & character & 9 & 0.31 & 民族 & Nationality & 5 & 0.17 \\
\hline 教师 & Teacher & 8 & 0.28 & 学校 & School & 5 & 0.17 \\
\hline 内容 & content & 8 & 0.28 & 祖国 & Motherland & 5 & 0.17 \\
\hline 综合性 & Synthesis & 8 & 0.28 & 表达 & Expression & 4 & 0.14 \\
\hline 思想 & Thought & 8 & 0.28 & 理解 & Comprehension & 4 & 0.14 \\
\hline
\end{tabular}

*Frequency.=frequency; \%=percentage among the whole amount of text words 
Table 5 Words with high frequency in Singapore's curriculum (Lexical density: 22.3322)

\begin{tabular}{|c|c|c|c|c|c|c|c|}
\hline Chinese gloss & English gloss & Freq. & $\%$ & Chinese gloss & English gloss & Freq. & $\%$ \\
\hline 学生 & Student & 77 & 2.82 & 意识 & Awareness & 7 & 0.26 \\
\hline 学习 & Learning & 71 & 2.60 & 华族 & Chinese people & 7 & 0.26 \\
\hline 教学 & Teaching & 47 & 1.72 & 过程 & Process & 7 & 0.26 \\
\hline 能力 & Ability & 46 & 1.69 & 思维 & Thinking & 7 & 0.26 \\
\hline 语言 & Language & 40 & 1.47 & 任务 & Task & 7 & 0.26 \\
\hline 教师 & Teacher & 32 & 1.17 & 阅读 & Reading & 7 & 0.26 \\
\hline 评价 & Assessment & 27 & 0.99 & 真实 & Authenticity & 6 & 0.22 \\
\hline 华文 & Chinese & 27 & 0.99 & 探究 & Exploration & 6 & 0.22 \\
\hline 课程 & Curriculum & 20 & 0.73 & 方式 & Method & 6 & 0.22 \\
\hline 技能 & Skill & 18 & 0.66 & 写作 & Writing & 6 & 0.22 \\
\hline 文化 & Culture & 16 & 0.59 & 重点 & Emphasis & 6 & 0.22 \\
\hline 资讯 & Information & 16 & 0.59 & 基础 & Basis & 6 & 0.22 \\
\hline 发展 & Development & 15 & 0.55 & 反馈 & Feedback & 5 & 0.18 \\
\hline 资源 & Resource & 15 & 0.55 & 口语 & Speaking & 5 & 0.18 \\
\hline 科技 & Technology & 15 & 0.55 & 教育 & Education & 5 & 0.18 \\
\hline 内容 & Content & 11 & 0.40 & 品德 & Morals & 5 & 0.18 \\
\hline 问题 & Question & 11 & 0.40 & 信息 & Information & 5 & 0.18 \\
\hline 互动 & Interaction & 10 & 0.37 & 协作 & Cooperation & 5 & 0.18 \\
\hline 目标 & Target & 9 & 0.33 & 自主 & Autonomy & 5 & 0.18 \\
\hline 生活 & Life & 9 & 0.33 & 自学 & Self-learning & 5 & 0.18 \\
\hline 设计 & Designation & 8 & 0.30 & 聆听 & Listening & 5 & 0.18 \\
\hline 交流 & Communication & 8 & 0.30 & 活动 & Activity & 5 & 0.18 \\
\hline 学校 & School & 8 & 0.30 & 引导 & Guiding & 5 & 0.18 \\
\hline 知识 & Knowledge & 8 & 0.30 & 策略 & Strategies & 5 & 0.18 \\
\hline 认知 & Cognition & 7 & 0.26 & 社区 & Community & 5 & 0.18 \\
\hline
\end{tabular}

*Freq.=frequency; \%=percentage among the whole amount of text words

\section{Funding}

The research is supported by Central University Fundamental Research (SWU1409181).

\section{Authors' contributions}

$\mathrm{MH}$ participated in the sequence alignment and designation of the research. She also participated in the collection and processing of data and drafted the manuscript. FB participated in the sequence alignment and performed the statistical analysis and drafted the manuscript. All authors read and approved the final manuscript.

\section{Competing interests}

The authors declare that they have no competing financial interests.

\section{Author details}

${ }_{1}^{1}$ College of International Studies, Southwest University, Tian Sheng Road, Beibei District, Chongqing 400715, China. ${ }^{2}$ Division of Linguistics and Multilingual Studies, Nanyang Technological University, 14 Nanyang Drive \#3-55, Singapore 637332, Singapore.

Received: 23 September 2016 Accepted: 8 November 2016

Published online: 18 November 2016

References

Abdual, K. H., \& Suraya, C. H. (2012). Autonomy in language learning. Journal of Education and Practice, 3(8), $103-111$. Adam, J. S. (2016). The successful incorporation of blended learning into the language curriculum. Advanced Education, 5, 96-107.

Ahmadian, M., \& Rad, S. E. (2014). Postmethod era and glocalized language curriculum development: A fresh burden on language teachers. Journal of Language Teaching and Research, 5(3), 592-598.

Antonio, L. R., \& Lionel, W. (Eds.). (2006). Language policy and modernity in Southeast Asia. USA: Springer. 
Baidu encyclopaedia. (2016). Chinese accomplishments. Retrieved from http://baike.baidu.com/view/1538830.htm. Accessed 1 Apr 2016.

Benson, P. (2001). Teaching and researching autonomy in language learning. Essex: Pearson Education Ltd.

Betty, L. (2014). Internationalizing the curriculum and all students' learning. International Higher Education, Special Issue: 5-6

Black, P., \& William, D. (2010). Inside the black box: Raising standards through classroom assessment. Phi Delta Kappan, 92(1), 81-90.

Breen, M. P. (2001). Syllabus design. In R. Carter \& D. Nunan (Eds.), The Cambridge guide to teaching English to speakers of other lanquages. Cambridge: Cambridge University Press.

Brown, J. D. (1995). The elements of language curriculum: A systematic approach to program development. Boston: Heinle \& Heinle Publishers

Burston, J. (2014). The reality of MALL: Still on the fringes. CALICO Journal, 31(1), 103.

Candlin, C. N. (1984). Syllabus design as a critical process. ELT Document, 118, 29-46.

Chinese Ministry of Education. (2006). A report on Chinese language and life. Beijing: Commercial Press.

Cullen, R., \& Harris, M. (2009). Assessing learner-centeredness through course syllabi. Assessment and Evaluation in Higher Education, 34, 115-125.

Dai, W., \& Hu, W. (2009). Research on the development of foreign language education in China (1949-2009). Shanghai: Shanghai Foreign Language Education Press.

Daly, N. (2009). Glocalizing foreign language teaching in Taiwan: Conditions and convergences. Zeitschrift Fur Interkulturellen Fremdsprachenunterricht, 14(1), 1-15.

Dickinson, L. (1987). Self-instruction in language learning. Cambridge: Cambridge University Press.

Dubin, F., \& Olshtain, E. (1986). Course design: Developing programs and materials for language learning. Cambridge: Cambridge university press.

Duman, G., Orhon, G., \& Gedik, N. (2015). Research trends in mobile assisted language learning from 2000 to 2012. ReCALL, 27(02), 197-216.

Gardner, J. (2010). Developing teacher assessment: An introduction. In J. Gardner, W. Harlen, L. Hayward, G. Stobart, \& M. Montgomery (Eds.), Developing teacher assessment. New York: Open University Press.

Hall, D. R., \& Hewings, A. (Eds.). (2001). Innovation in English language teaching: A reader. London: Routledge.

Hans D.W., \& Betty, L. (2015). Internationalization, the curriculum and the disciplines. International Higher Education, Special Issue: 10-12

Harlen, W., \& Gardner, J. (2010). Assessment to support learning. In J. Gardner, W. Harlen, L. Hayward, G. Stobart, \& M. Montgomery (Eds.), Developing teacher assessment. New York: Open University Press.

Holec, H. (1981). Autonomy in foreign language learning (1st ed.). Oxford: Pergamon.

Imtiaz, H. T., Norrihan, B. S., \& Muhammad, A. S. (2016). Impact of mobile assisted language learning (MALL) on EFL:1 A meta-analysis. Advances in Language and Literacy Studies, 7(2), 76-83.

Jacobs, G. M., \& Farewell, T. S. C. (2003). Understanding and implementing the CLT (Communicative language teaching) Paradigm. RELC Journal, 34(1), 5-30.

Knight, P. (2000). The value of a programme-wide approach to assessment. Assessment and Evaluation in Higher Education, 25, 237-251.

Li, D. D. (2008). Issues in Chinese language curriculum and material development. In P. Duff \& P. Lester (Eds.), Issues in Chinese Language Education and Teacher Development. Canada: Center for Research in Chinese Language and Literacy Education, University of British Columbia. Retrieved from http://www. academia.edu/9682120/Issues_in_Chinese_Language_Education_and_Teacher_Development_-_2008. Accessed 1 Apr 2016.

Maguire, M. (2002). Globalisation, education policy and the teacher. International Studies in Sociology of Education, 12(3), 261-276.

$\mathrm{Na}$, L. (2010). The Chinese language and lanquage planning in China. Washington DC: Center for Applied Linguistics. Retrieved from http://www.cal.org/heritage/. Accessed 1 Apr 2016.

Nunan, D. (1993). Task-based syllabus design: Selecting, grading and sequencing tasks. In G. Crookes \& S. M. Gass (Eds.), Tasks in a Pedagogical Context. Cleveland: Multilingual Matters.

Pienemann, M. (1985). Learnability and syllabus construction. In Hyltenstam \& Pienemann (Eds.), Modeling and assessing second language acquisition. Clevedon, Avon: Multilingual Matters.

Reynolds, C. R., Livingston, R. B., \& Wilson, V. (2006). Measurement and Assessment in Education. Boston: Pearson.

Richards, J. C. (2001). Curriculum development in language teaching. New York: Cambridge University Press.

Robertson, R. (1995). Globalisation: Time-space and homogeneity-heterogeneity. In M. Featherstone, S. Lash, \& R. Robertson (Eds.), Global modernities. London: Sage publications Ltd.

Sinor, J., \& Kaplan, M. (2010). Creating your syllabus. University of Michigan GSI Guidebook. Retrieved from http://crlt.umich.edu/gsis/p2_1. Accessed 1 Apr 2016.

Slattery, J. M., \& Carlson, J. F. (2005). Preparing an effective syllabus: current best practices. College Teaching, 54(4), $159-164$.

Stephen, D. K. (2002). Second Language Acquisition and Second Language Learning. Oxford: Pergamon Press.

Stern, H. H. (1992). Issues and options in language teaching. Oxford: Oxford university press.

Susan, M. G., \& Larry, S. (2008). Second Language Acquisition: An Introductory Course. New York: Routledge.

Tayebeh, N. M., \& Amin, N. (2012). Mobile-Assisted language learning. International Journal of Distributed and Parallel Systems, 3(1), 309-319.

Thompson, B. (2007). The syllabus as a communication document: Constructing and presenting the syllabus. Communication Education, 56(1), 54-71.

Warschauer, M. (1999). Electronic literacies: Language, culture, and power in online education. Mahwah: Lawrence Erlbaum Associates.

Wiggins G., \& McTighe J. (2007). Understanding by Design: A Framework for Effecting Curricular Development and Assessment. CBE Life Sciences Education, 6(2): 95-97. Retrieved from http://www.ncbi.nlm.nih.gov/pmc/articles/ PMC1885909/. Accessed 1 Apr 2016. 
Wikipedia. (2016). Speak Mandarin Campaign. Retrieved from https://en.wikipedia.org/wiki/Speak_Mandarin_Campaign. Accessed 1 July 2016

William, D. (2011). What is assessment for learning? Studies in Educational Evaluation, 37(1), 3-14.

Willinghan-McLain, L. (2011). Using a universityOwide syllabus study to examine learning outcomes and assessment. Journal of Faculty Development, 25(1), 43-53.

Yang, J. (2013). Mobile assisted language learning: review of the recent applications of emerging mobile technologies. English Language Teaching, 6(7), 19-25.

Yorke, M. (2003). Formative assessment in higher education: Moves towards theory and the enhancement of pedagogic practice. Higher Education, 45, 477-501.

Zhou, Y. G. (2001). Language planning of China. Journal of Asian Pacific Communication, 11(1), 9-16.

Submit your manuscript to a SpringerOpen ${ }^{\odot}$ journal and benefit from:

- Convenient online submission

- Rigorous peer review

- Immediate publication on acceptance

- Open access: articles freely available online

- High visibility within the field

- Retaining the copyright to your article

Submit your next manuscript at $>$ springeropen.com 